*ak RMIS View/Frint Document Cover Sheet tow

This document was retrieved from the Documentation and Records Manaqement (DRM) ISEARCH System. It is intended for Information only and may not be the most recent or updated version. Contact a Document Service Center (see Hanford Info for locations) if you need additional retrieval information.

Accession \#: D196045545

Document \#: SD-SNF-ATR-016

Title/Desc:

ACCEPTANCE TEST REPORT FOR THE HIGH PRESSURE WATER JET SYSTEM FEED PUMP

Pages: 15 
2. To: (Receiving Organization)

SNF K-BASINS PROJECTS

5. Proj./Prog./Dept./Div.:

Spent Nuclear Fuel

8. Originator Remarks:

For Release
3. From: (Originating Organization) 4 4. Related EOT No.: SNF K-BASINS PROJECTS

6. Cog. Engr.:

J. B. Crystal

140394
7. Purchase Order №.: N/A

9. Equip./Component No.: $\mathrm{N} / \mathrm{A}$

10. System/B1dg./Facility: 105-KE

12. Major Assm. Dwg. No.: $\mathrm{N} / \mathrm{A}$

13. Permit/Permit Application No. :

N/A

14. Required Response Date:

N/A

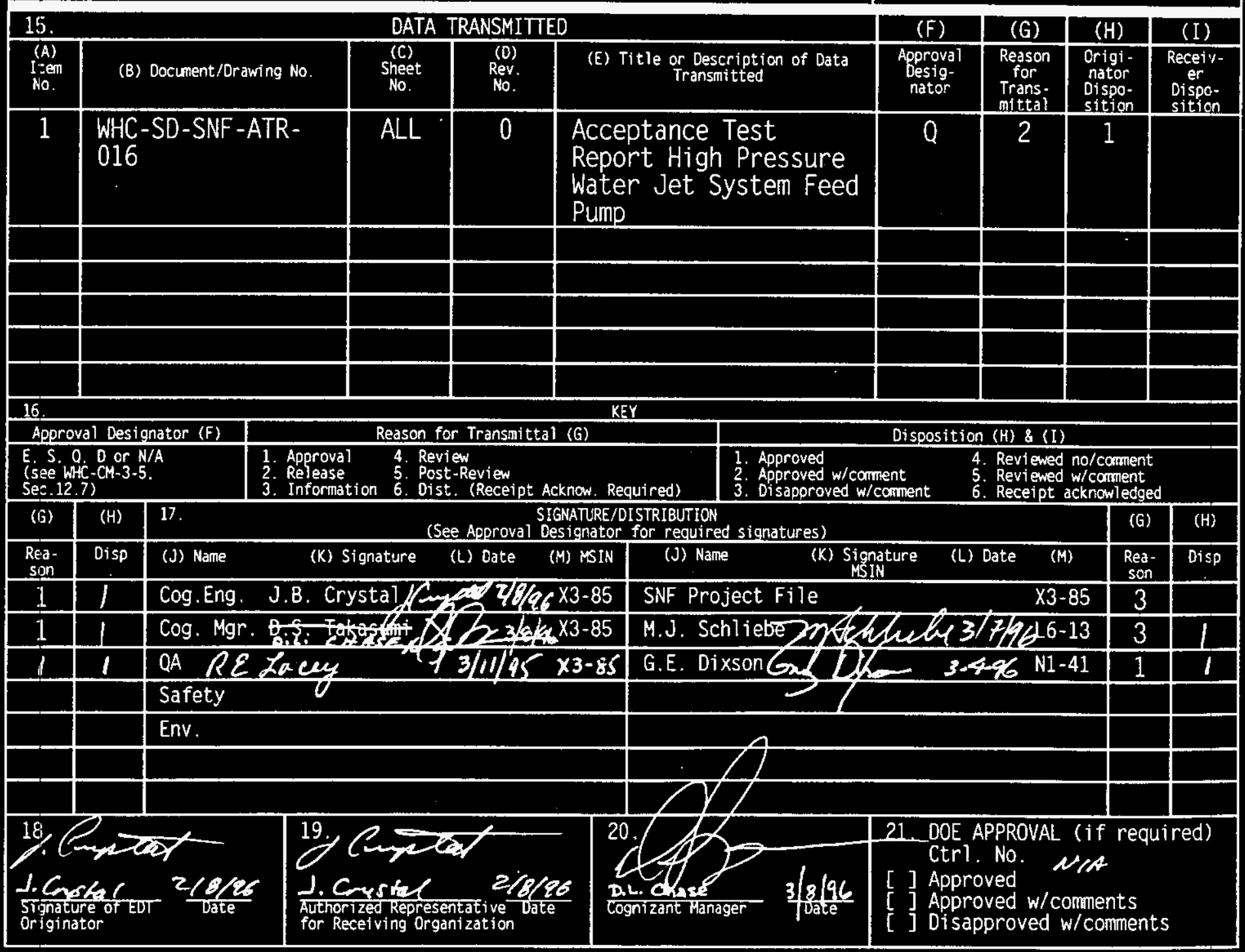

BD-7400-172-2 (04/94) GEF097 


\section{Acceptance Test Report for the High Pressure Water Jet System Feed Pump}

Jeremy B. Crystal

Westinghouse Hanford Company, Richland. WA 99352

U.S. Department of Energy Contract DE-AC06-87RL10930

EDT/ECN: 140394

140399 (JEA $3 / 1196$ )

Org Code: 2G000

UC: 510

Charge Code: L0054

B\&R Code: EW3135040

Total Pages: 13

Key Words: HPWJS, Feed, Canister. Debris, Acceptance

Abstract: This document summarizes results of WHC-SD-SNF-ATP-016, Rev. 0 . Acceptance Test Procedure High Pressure Water Jet System, conducted on December 20, 1995 and December 22, 1995.

TRADEMARK DISCLAIMER. Reference herein to any specific commercial product, process, or service by trade name, trademark. manufacturer. or otherwise, does not necessarily constitute or imply its endorsement, recommendation, or favoring by the United States Government or any agency thereof or its contractors or subcontractors.

Printed in the United States of America. To obtain copies of this document, contact: WHC/BCS Document Control Services, P.O. Box 1970. Mailstop H6-08. Richland WA 99352. Phone (509) 372-2420; Fax (509) 376-4989.
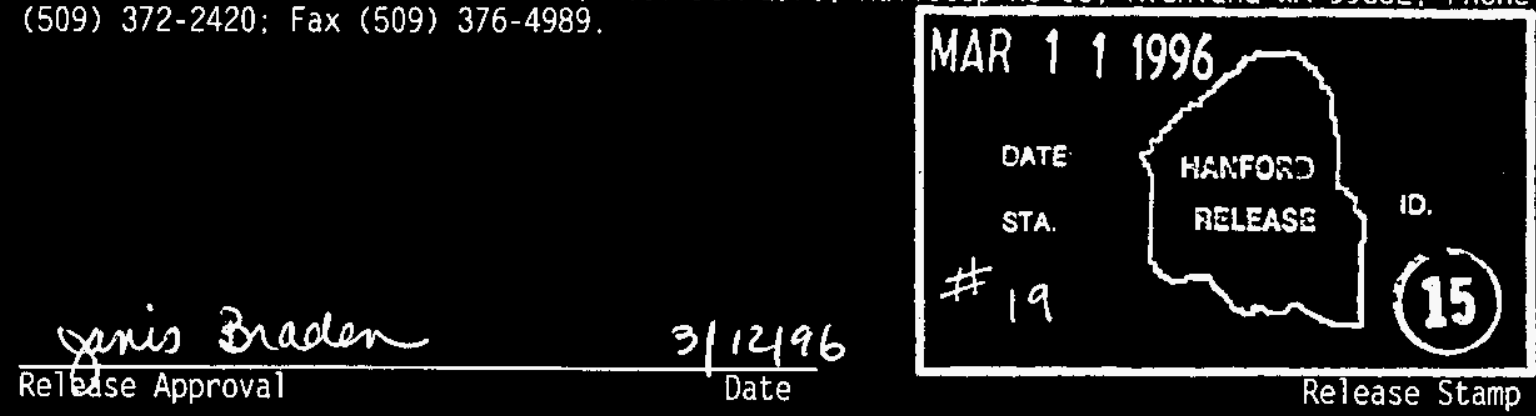

\section{Approved for Public Release}




\section{TABLE OF CONTENTS}

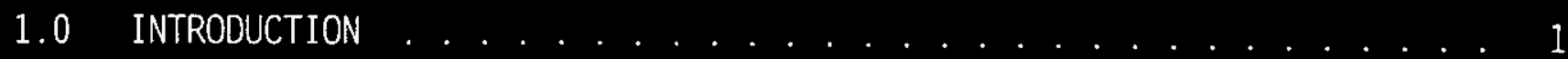

2.0 DESCRIPTION OF TEST . . . . . . . . . . . . . . . . . . . . 1

3.0 TEST METHOD AND TEST EQUIPMENT . . . . . . . . . . . . . 2

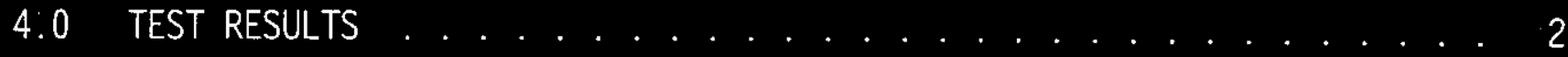

5.0 CONCLUSIONS AND RECOMMENDATIONS . . . . . . . . . . . . . . 3

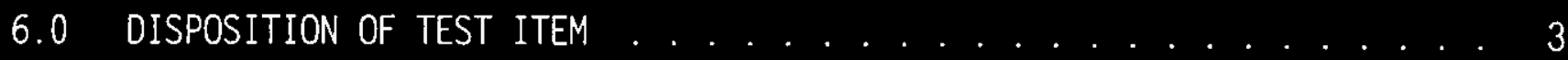

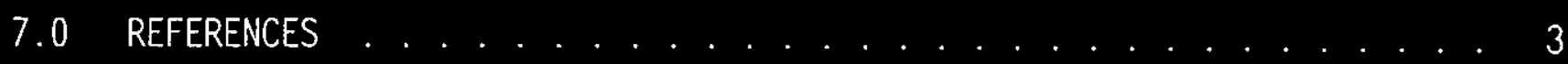

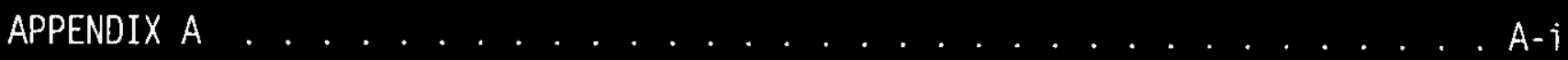

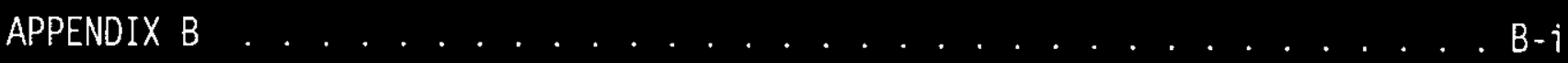


WHC-SD-SNF-ATR-016, Rev. 0

\subsection{INTRODUCTION}

Acceptance testing of the High Pressure Water Jet System, without a skid mounted feed pump. was performed earlier in the year under a separate acceptance test procedure (WHC-SD-SNF-ATP/ATR-010, Rev. 0). For this earlier testing the HPWJS configuration consisted of a skid supporting a Butterworth high pressure water pump, surge tank, electrical disconnect and controller, pressure adjustment controls, and associated hoses.

The HPWJS supplies water at high pressure $(15,000 \mathrm{psi}$ @ $15 \mathrm{gpm})$ to nozzles specially designed to clean the surfaces of empty fuel storage canisters. The nozzles are part of a Canister Cleaning Station consisting of metal girder framework. foot pedal manifold to direct water. associated hoses. operating controls, and an underwater support table designed to hold empty fuel storage canisters during cleaning. The skid and it's attached equipment will be remotely located and connected to the canister cleaning station by a high pressure water supply hose.

Acceptance testing of the High Pressure Water Jet System (HPWJS) Feed Pump was performed in the 305 Building Cold Test Facility on the 20th and 22nd of December, 1995. Testing was conducted for the Spent Nuclear Fuel group per WHC-SD-SNF-ATP-016, Rev. 0 . The following personnel were involved in the test:

* Greg Dixson. Engineer. FMEF Operations/Engineering (work ordered to SNF Engineering Support)--Test Engineer.

* Dennis Larson, Technician, Engineering Test Lab (305 Building)--HPWJS Technician.

* Bob Loper. Technician. Engineering Test Lab (305 Bui 1ding)--Safety observer.

* $\quad$ Art Fleming. Engineer, Master-Lee Company--HPWJS Operator.

\subsection{DESCRIPTION OF TEST}

Subsequent to the original acceptance testing of the HPWJS, a feed pump was installed to ensure a positive suction head to the Butterworth pump during system operation. A submersible pump was used previously as a temporary method of supplying feed water to the HPWJS. Technical data for the pump is as follows:

Manufacturer or supplier: Manufacturer's designation: Model number:

Part number:

Serial number:
March Manufacturing, Inc.

TE-7.5K-MD "Orbita1" Magnetic Drive Pump 2VF182TTFR5501BEP

$156-008-10$

KK-77224 
This test was performed to verify that the model TE-7.5K-MD "Orbital" Magnetic Drive Pump complied with acceptance criteria defined in Section 2.3 of WHC-SD-SNF-ATP-016, Rev. 0. The pump was required to: (1) maintain pressure in the skid mounted surge tank at greater than 30 psi for the duration of the test. while (2) having no visual signs of leakage for the duration of the test.

\subsection{TEST METHOD AND TEST EQUIPMENT}

The acceptance test consisted of starting up the HPWJS and verifying proper system response prior to entering into the testing. Electrical indications were as expected on the pump's controller. The white "Power on" light was lit with power to the controller. Starting the feed pump caused the green "Run" light to illuminated, and shutting down the pump caused the light to extinguish.

With the initial system operation as expected the testing began. The HPWJS was brought up to pressure $(12,000-15,000$ psi) and each foot pedal was depressed (allowing flow through the corresponding nozzles) in alternating 3 minute increments. During each 3 minute period the surge tank pressure was observed and recorded. During this time the piping and feed pump were monitored for leaks.

Surge tank pressure was monitored using the surge tank pressure gage, PI100 (Standard's Lab Calibration sticker number 752-31-04-084). The jights in question were mounted on the feed pump control station.

\subsection{TEST RESULTS}

The pump's controller displayed the proper electrical indications. Power applied to the controller lit the white "Power On" light. When the start button was depressed. the green "Run" light illuminated, and when the pump was stopped the green "Run" light extinguished.

For all three nozzles operating with a Butterworth pump discharge pressure of 15,000 psig, the surge tank pressure (PI-100) was 38 psig. This pressure remained constant throughout the test.

The feed pump and it's piping were inspected at the start of the test and each time the technician shifted nozzles. At the end of the three minute operation of the hand lance (step 6.5 of the acceptance test traveler) the last of the nozzles to be operated, a small leak, or "weep", was noted on the union on the discharge side of the feed pump.

Having already completed step 6.5 and recorded the data for step 6.6, the Test Engineer decided to proceed to step 6.7. shut down the HPWJS and the feed pump and repair the leak, then retest the pump for leaks as an "Exception". The Test Technician located a new union the next day and 
replaced the leaking union. The leaking union had a scored mating surface. The next morning December the 22nd, the Test Engineer and Test Technician ran the feed pump for 10 minutes on it's own. There were no leaks on the feed pump or it's associated piping or fittings. This "Exception" was recorded in the Notes column of the test traveler (Appendix B) next to Operation 7.0 .

\subsection{CONCLUSIONS AND RECOMMENDATIONS}

The Test Engineer was satisfied that the newly installed TE-7.5K-MD

"Orbital" Magnetic Drive High Pressure Water Jet System Feed Pump satisfied al1 acceptance test criteria, as listed in section 2.3 of WHC-SD-SNF-ATP016, Rev. 0.

\subsection{DISPOSITION OF TEST ITEM}

The HPWJS skid is destined for eventual relocation to the 105-KE Basin in support of the Debris Removal Project. Use of the HPWJS in the KE Basin may occur following the release of the Acceptance Test Report and revising the drawings to "as-built".

\subsection{REFERENCES}

WHC-SD-SNF-ATP-016, Rev. 0; Acceptance Test Procedure High Pressure Water Jet System Feed Pump

WHC-IP-1026, Rev. 1; Engineering Practice Guidelines, Appendix K. Figure 4 
WHC-SD-SNF-ATR-016, Rev. 0

APPENDIX A

COMPLETED SAFETY CHECKLIST

FOR THE HIGH PRESSURE WATER JET SYSTEM

$A-j$ 


\begin{tabular}{|c|c|c|c|}
\hline \multicolumn{4}{|c|}{ ATTACHMENT A - SAFETY CHECKLIST FOR THE HPWJS } \\
\hline \multicolumn{4}{|c|}{ DATE: $12.20-95 \quad$ TIME: $9: 00 \wedge \mathrm{M}$} \\
\hline \multicolumn{2}{|c|}{ INSPECTION PERFORMED BY: } & Yes & No \\
\hline 1. & Has the Pre Job briefing been completed? & $レ$ & \\
\hline 2. & Are personnel trained and qualified to operate the HPWJS? & 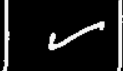 & \\
\hline 3. & Is personnel safety equipment available at the job site? & $V$ & \\
\hline 4. & $\begin{array}{l}\text { Has the work area and the skid area both been roped off with } \\
\text { proper signs posted? }\end{array}$ & & \\
\hline 5. & Have precautions been taken to protect electrical equipment? & $V$ & \\
\hline 6. & Is the area cleared of tripping hazards? & $\checkmark$ & \\
\hline 7. & 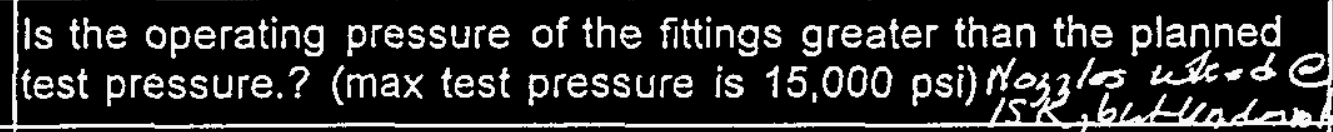 & & \\
\hline 8. & $\begin{array}{l}\text { Are all hoses, lances, guns and foot control valves rated for the } \\
\text { maximum operating pressure? }\end{array}$ & & \\
\hline 9. & $\begin{array}{l}\text { Are all fittings, hoses, lances, guns and foot control valves in } \\
\text { good working condition? }\end{array}$ & & \\
\hline 10. & $\begin{array}{l}\text { Is the feed water pump properly placed in the basin and } \\
\text { connected to the pump skid and has it been flushed? }\end{array}$ & & \\
\hline 11. & $\begin{array}{l}\text { Have the Filter and Y-strainer been checked for cleanliness and } \\
\text { in good operating condition? }\end{array}$ & & \\
\hline 12. & $\begin{array}{l}\text { Are the skid drains, cooling water and dump water properly } \\
\text { routed? }\end{array}$ & & \\
\hline 13. & Are the safety shrouds on guns, valves and hoses? & $\checkmark$ & \\
\hline 14. & $\begin{array}{l}\text { Confirm electrical service connections are properly connected and } \\
\text { power from the Portable Generator is available? }\end{array}$ & & \\
\hline 15. & $\begin{array}{l}\text { Has the high pressure hoses been flushed and all air removed } \\
\text { prior to nozzle being installed? }\end{array}$ & & \\
\hline 16. & Is the cooling water to the plungers operating properly? & $r$ & \\
\hline 17. & $\begin{array}{l}\text { Has the oil level been checked on the sight glass for the power } \\
\text { end? }\end{array}$ & & \\
\hline 18. & $\begin{array}{l}\text { Has the Pressure Regulator been charged with nitrogen to the } \\
\text { desired operating pressure? }\end{array}$ & & \\
\hline
\end{tabular}




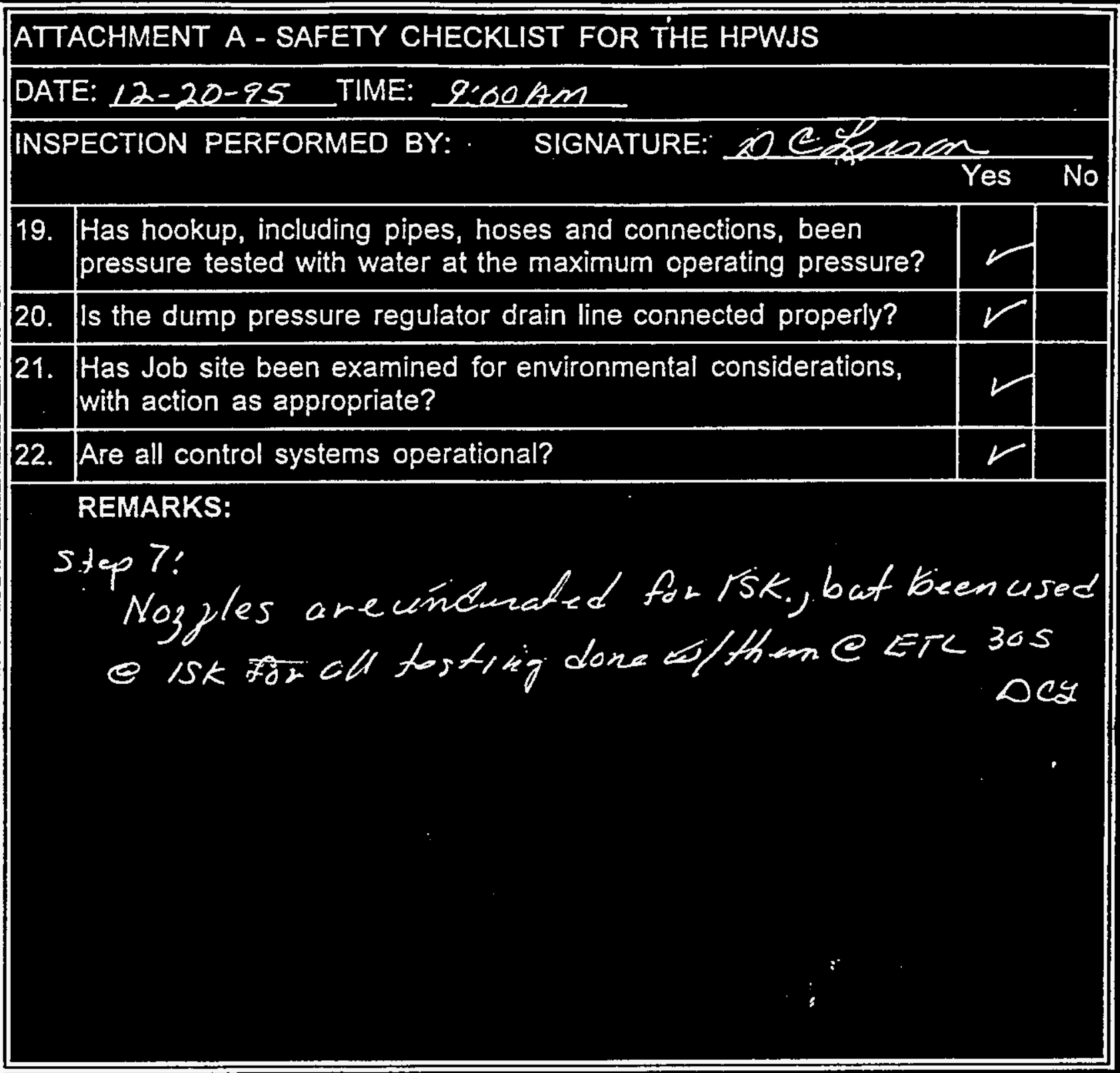


WHC-SD-SNF-ATR-016, Rev. 0

\section{APPENDIX B \\ COMPLETED TEST TRAVELER \\ FOR THE HIGH PRESSURE WATER JET SYSTEM}

$B-j$ 


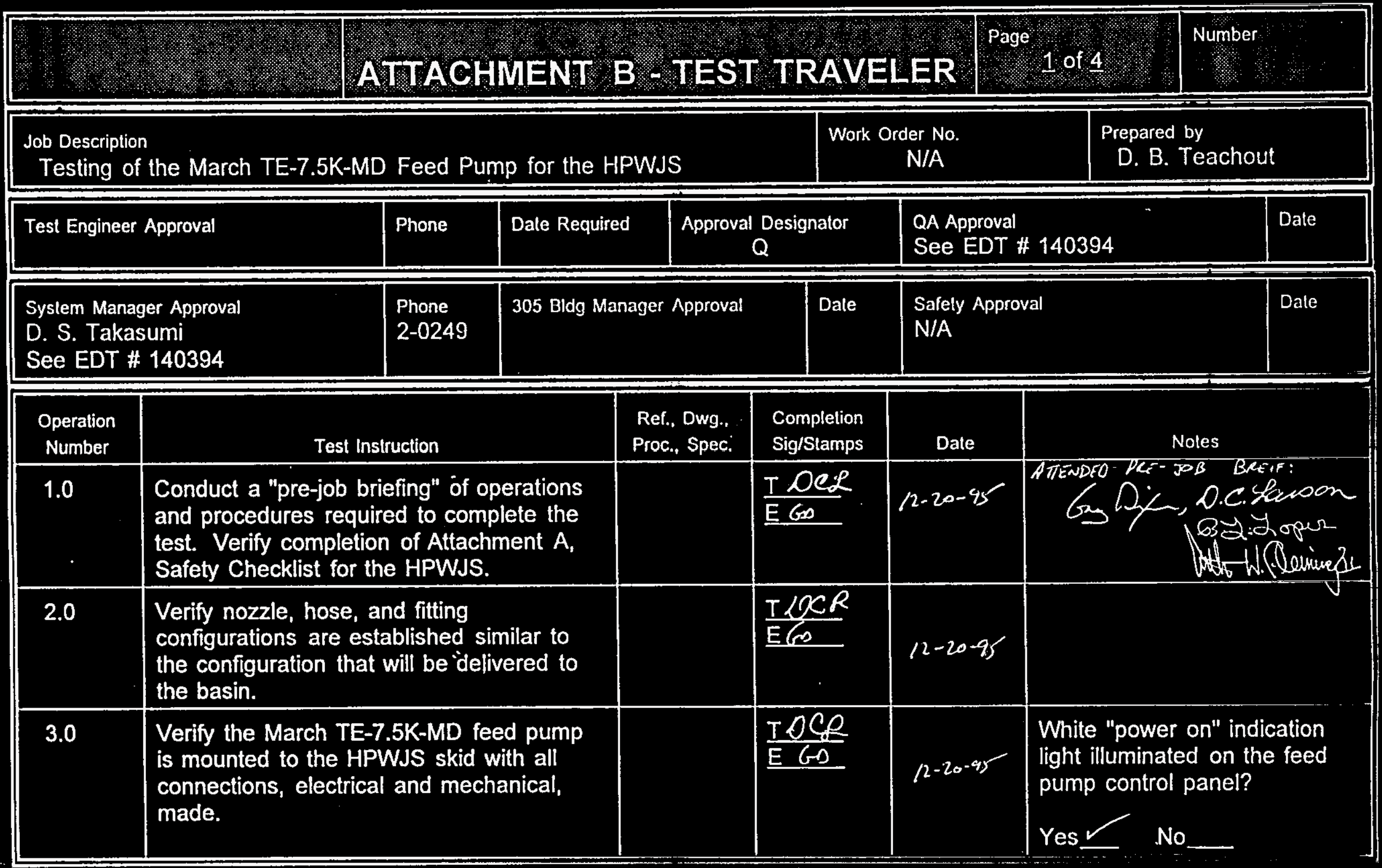




\begin{tabular}{|c|c|c|c|c|c|}
\hline \multicolumn{3}{|c|}{ TEST TRAVELER (continuation sheet) } & \multicolumn{2}{|c|}{ Page 2 of $\underline{4}$} & Number \\
\hline $\begin{array}{c}\text { Operalion } \\
\text { Number }\end{array}$ & Test Instruction & $\begin{array}{l}\text { Ref., Dwg., } \\
\text { Proc., Spec. }\end{array}$ & $\begin{array}{l}\text { Completion } \\
\text { Sig/Stamps }\end{array}$ & Dale & Notes \\
\hline 4.0 & $\begin{array}{l}\text { Calibration Checks: Verify that the surge } \\
\text { tank pressure gauge, } \mathrm{PI}-100 \text {, has valid } \\
\text { calibration data. }\end{array}$ & & $\frac{T D C Z}{E 60}$ & $12-2025$ & $\begin{array}{l}\text { STRWDARDS LAB STICKER \# } \\
752-31-04-084\end{array}$ \\
\hline $5.0^{\circ}$ & $\begin{array}{l}\text { Start up the HPWJS per standard } \\
\text { operating procedure and raise pressure to } \\
\text { greater than } 13,000 \text { psi. Maintain pressure } \\
\text { between } 13,000-15,000 \text { psi throughout } \\
\text { the test. } \\
\text { Conduct a quick visual check of the } \\
\text { system and indicate the appropriate } \\
\text { responses to the questions in the NOTES } \\
\text { column. }\end{array}$ & & $\frac{\text { TDey }}{E \text { lo }}$ & 12.20 .95 & $\begin{array}{l}\text { Green "run" light illuminated } \\
\text { on the feed pump control } \\
\text { panel? } \\
\text { Any leakage noted from the } \\
\text { feed pump? } \\
\text { Yes__ No_ } \\
\text { range of } 30-60 \text { psi? } \\
\text { Yes }\end{array}$ \\
\hline 6.0 & $\begin{array}{l}\text { Run the HPWJS per the following } \\
\text { sequence. }\end{array}$ & & & & \\
\hline 6.1 & $\begin{array}{l}\text { Depress the foot pedal for the interior } \\
\text { cleaning nozzle. Hold in this position for } 3 \\
\text { minutes. }\end{array}$ & & $\frac{\mathrm{TOCH}}{\mathrm{E} G 0}$ & $12-2 v-95$ & $\begin{array}{l}38 \text { PSG } \\
092-0915\end{array}$ \\
\hline
\end{tabular}

TEST CONTROL COPY 


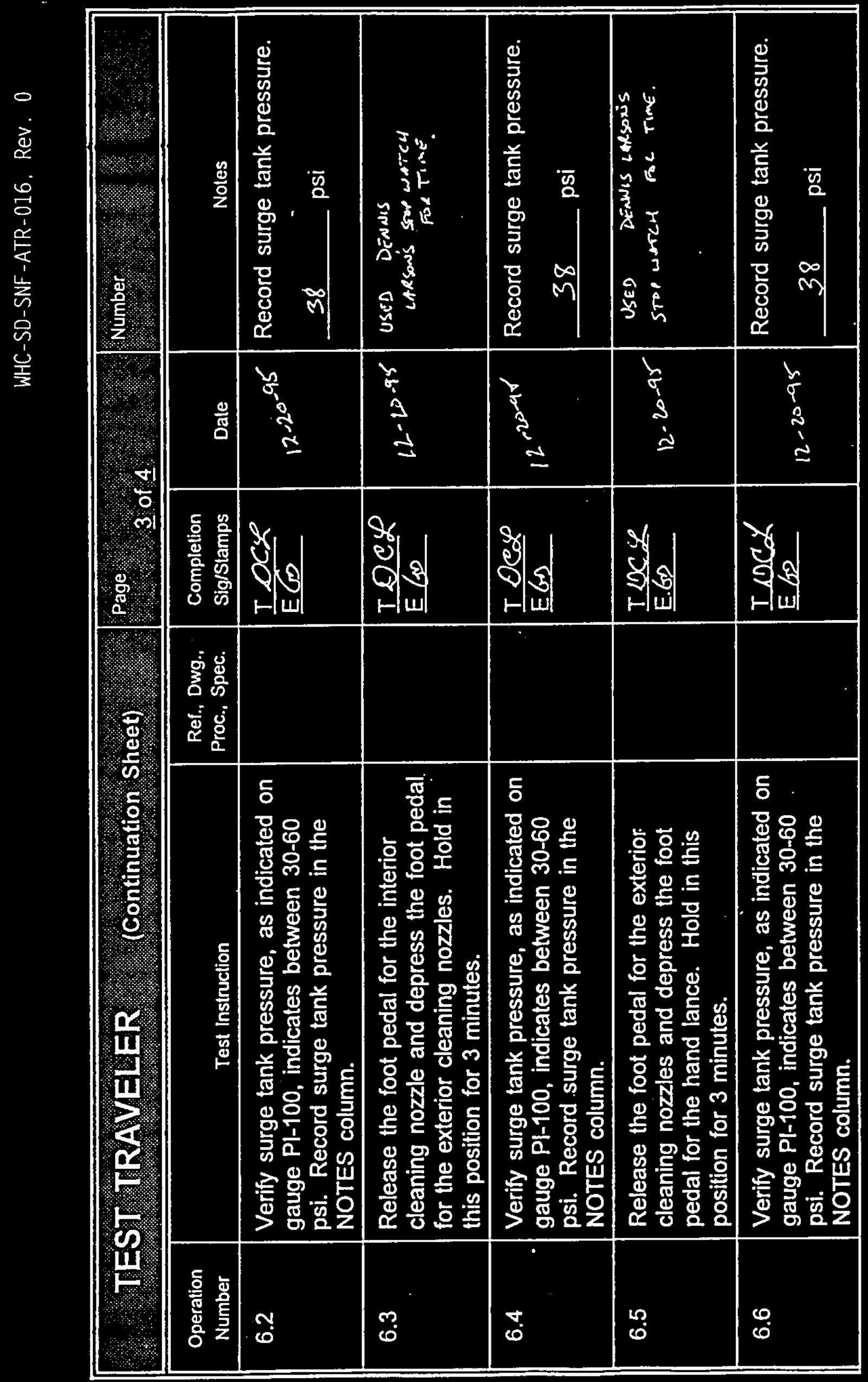

m

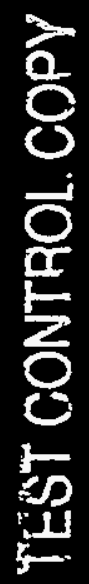




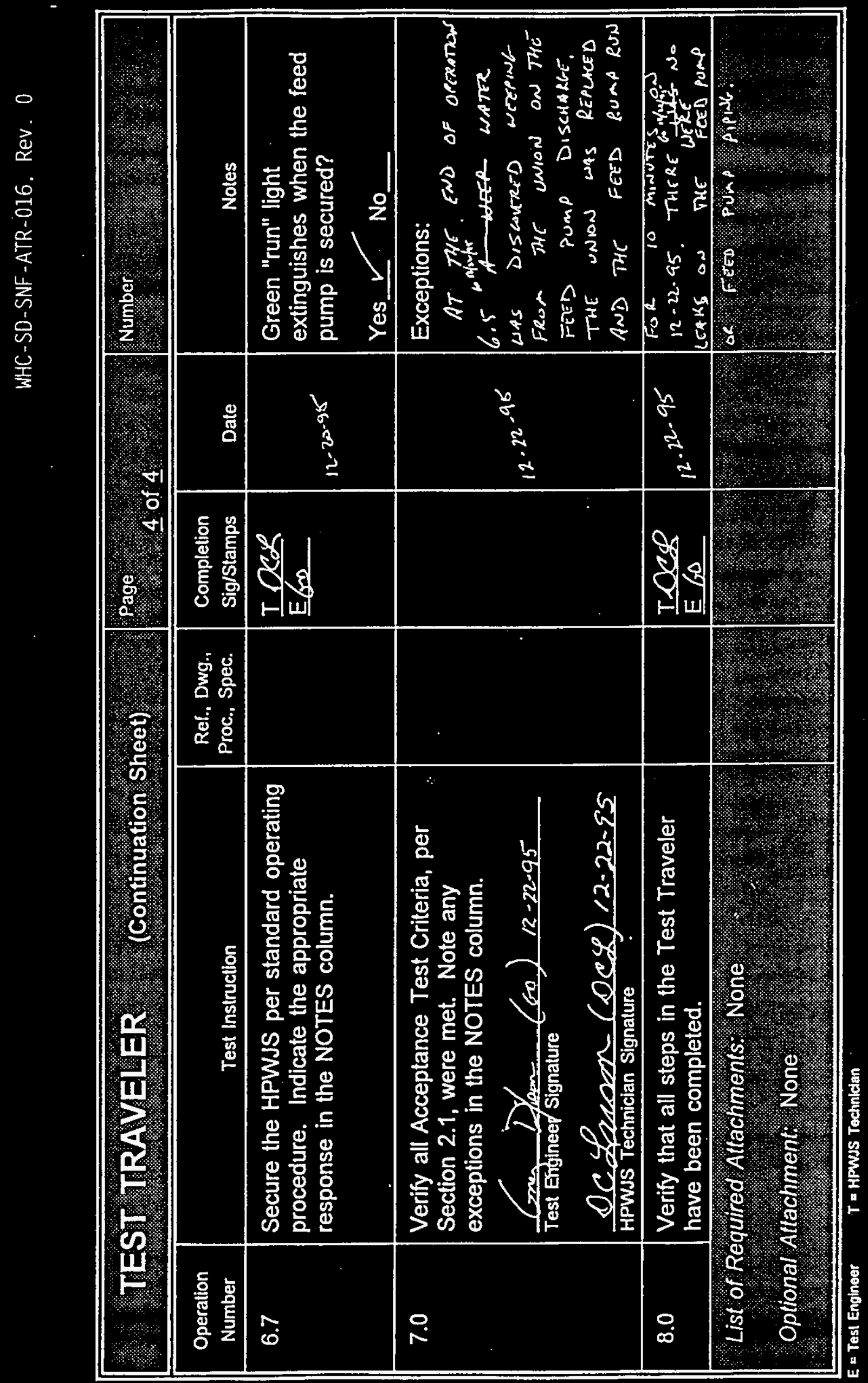

i 